\title{
RESEARCH
}

Open Access

\section{Success factors for high-quality oak forest (Quercus robur, Q. petraea) regeneration}

\author{
Andreas Mölder ${ }^{1 *} \mathbb{D}$, Holger Sennhenn-Reulen', Christoph Fischer ${ }^{1}$, Hendrik Rumpf ${ }^{2}$, Egbert Schönfelder ${ }^{1}$,
} Johannes Stockmann ${ }^{1}$ and Ralf-Volker Nagel ${ }^{1}$

\begin{abstract}
Background: Within the framework of close-to-nature forestry, oak forest (Quercus robur, Q. petraea) regeneration techniques that consider both silvicultural and nature conservation demands have become a very important issue. While there are many experimental and local studies that aim at disentangling the relationships between different environmental and silvicultural factors and the success of oak regeneration, systematic supra-regional studies at the greater landscape level are missing so far.

Against this background, the first objective (a) of this study was to present an efficient and sufficiently accurate sampling scheme for supra-regional forest regrowth inventories, which we applied to young oaks stands. The second, and major, objective (b) was to identify the crucial success factors for high-quality oak forest regeneration in northwest Germany.

Results: Objective (a): Factors that have been identified as potentially crucial for the success or failure of oak regeneration were either included in a field inventory procedure or extracted from forest inventory databases. We found that the collected data were suitable to be analyzed in a three-step success model, which was aimed at identifying the crucial success factors for high-quality oak forest regeneration.

Objective (b): Our modeling procedure, which included a Bayesian estimation approach with spike-and-slab priors, revealed that competitive pressure from the secondary tree species was the most decisive success factor; no competition, or low competition by secondary tree species appeared to be particularly beneficial for the success of high-quality oak regeneration. Also fencing and the absence of competitive vegetation (weeds, grass, bracken) seemed to be beneficial factors for the success of oak regeneration.

Conclusions: Trusting in biological automation was found to be mostly useless regarding economically viable oak forest regeneration. To efficiently organize oak regeneration planning and silvicultural decision-making within a forest enterprise, it is strongly recommended to initially evaluate the annual financial and personnel capacities for carrying out young growth tending or pre-commercial thinning and only then to decide on the extent of regenerated oak stands. Careful and adaptive regeneration planning is also indispensable to secure the long-term ecological continuity in oak forests. Oak regeneration should therefore preferably take place within the close vicinity of old oak stands or directly in them. The retention of habitat trees is urgently advised.
\end{abstract}

Keywords: Close-to-nature forestry, Competition, Ecological continuity, Forest inventory, Forest management, Plantplant interactions, Quercus robur, Quercus petraea, Regeneration, Silviculture

\footnotetext{
*Correspondence: moelder@gmx.de; andreas.moelder@nw-fva.de

${ }^{1}$ Department A (Forest Growth), Northwest German Forest Research Institute

(NW-FVA), Grätzelstraße 2, D-37079 Göttingen, Germany

Full list of author information is available at the end of the article
} 


\section{Background}

Oak forests in Central Europe with pedunculate oak (Quercus robur) and sessile oak (Q. petraea) are highly valued by forestry and nature conservation, since they frequently provide both high quality timber and a rich and typical biodiversity (Lüpke 1998; Brändle and Brandl 2001; Löf et al. 2016; Leuschner and Ellenberg 2017; Mölder et al. 2019). Within the framework of close-tonature forestry (Pommerening and Murphy 2004; Brang et al. 2014), oak forest regeneration techniques that consider both silvicultural and nature conservation demands have become a very important issue. Not only the appropriate size of canopy openings, but also the suitability and implementation of natural regeneration, planting or seeding have been discussed intensively (Lüpke 1998; Dobrowolska 2008; Saha et al. 2012; Annighöfer et al. 2015; Skiadaresis et al. 2016; Collet et al. 2017; Dillen et al. 2017). We contribute to this line of research by analyzing data from large-scale field inventories and aim to identify the crucial factors for successful oak regeneration.

Since the emergence of modern or scientific forestry in the mid-eighteenth century (Hölzl 2010), foresters have been searching for effective and cost-efficient methods to regenerate oak forests (Jacobi 1761; Sierstorpff 1796; Fuchs 1824; Burckhardt 1870; Manteuffel 1874; Krahl-Urban 1959). In this regard, the timeconsuming reduction of weed competition (Jacobi 1761; Humphrey and Swaine 1997; Collet et al. 1998) and the prevention of rodent and deer browsing damage are recurrent themes in forestry literature (Jacobi 1761; Ratzeburg 1860; Birkedal et al. 2009; Jensen et al. 2012). In particular, strong competition by the shade-tolerant European beech (Fagus sylvatica) has been identified early as problematic for young oak trees, which are more light-demanding (Kunkel 1830; Brumhard 1843; Gayer 1884; Otto et al. 2009; Ligot et al. 2013). In this context, the appropriate size and shape of canopy openings has also been intensively discussed since the nineteenth century (Gayer 1884, 1886; Lüpke 1998; Diaci et al. 2008; Březina and Dobrovolný 2011). Competition by early successional broadleaved tree species like birches (Betula spp.) and willows (Salix spp.) has also long been known to be a crucial factor influencing the growth of young oaks (Anonymus 1869; Burckhardt 1870; Ammer and Dingel 1997; Wagner and Röker 2000).

While there are many current experimental and local studies that aim at disentangling the relationships between different environmental and silvicultural factors and the success of oak regeneration (Löf et al. 2006; Ostrogović et al. 2010; Březina and Dobrovolný 2011; Ligot et al. 2013; Annighöfer et al. 2015; Jensen and Löf 2017), systematic supra-regional studies at the greater landscape level are missing so far. Against this background, we have designed and implemented a sampling scheme that is based on forest inventory data and field inventories within the whole area of northwest Germany. The selection of the study sites was statistically optimized to improve representativeness. Considering a high sample size in a large area, our approach aimed to both collect data in sufficient quality and to achieve an efficient work progress. We selected potentially relevant environmental and silvicultural factors that have been highlighted in the literature. The data were either recorded using a carefully developed field protocol or extracted from forest inventory databases.

The term "success" is not strictly defined when referring to oak regeneration. From the perspective of silviculture, successful oak regeneration should not deviate from defined stem densities, and competition pressure by surrounding vegetation should be optimized, so that stable and productive stands with high timber quality develop (Lüpke 1998; Petucco et al. 2013; Skrzyszewski and Pach 2015; Kamler et al. 2016). From the nature conservation point of view, the survival of several young oaks that grow up to mature and structure-rich trees might be considered as success (Reif and Gärtner 2008; Petucco et al. 2013; Götmark and Kiffer 2014). In this study, we follow the silvicultural perception of regeneration success and consider it necessary to conduct economically viable oak forestry within integrative multifunctional forest management schemes (Borrass et al. 2017). This also implies that a number of structurally suitable oak trees has to be retained as habitat trees (Bütler et al. 2013).

Our objective, therefore, is twofold. First, we present an efficient and sufficiently accurate sampling scheme for supra-regional forest regrowth inventories, which we apply to young oaks stands. Secondly, we analyze the gathered data in a three-step success model, in order to identify the crucial success factors for high-quality oak forest regeneration. The results obtained should serve as an objective component in the silvicultural decisionmaking processes within the framework of close-tonature forestry.

\section{Methods \\ Study area}

The study was conducted in northwest Germany and covered the federal states Lower Saxony, Saxony-Anhalt, Hesse and Schleswig-Holstein (Fig. 1). From the Pleistocene lowlands over river floodplains to the low mountain ranges, a variety of landscape types and site conditions were represented. There is a climatic gradient from oceanic conditions in the west to more continental regions in the east. Both woodland cover and composition vary considerably within the study area (Gauer and 


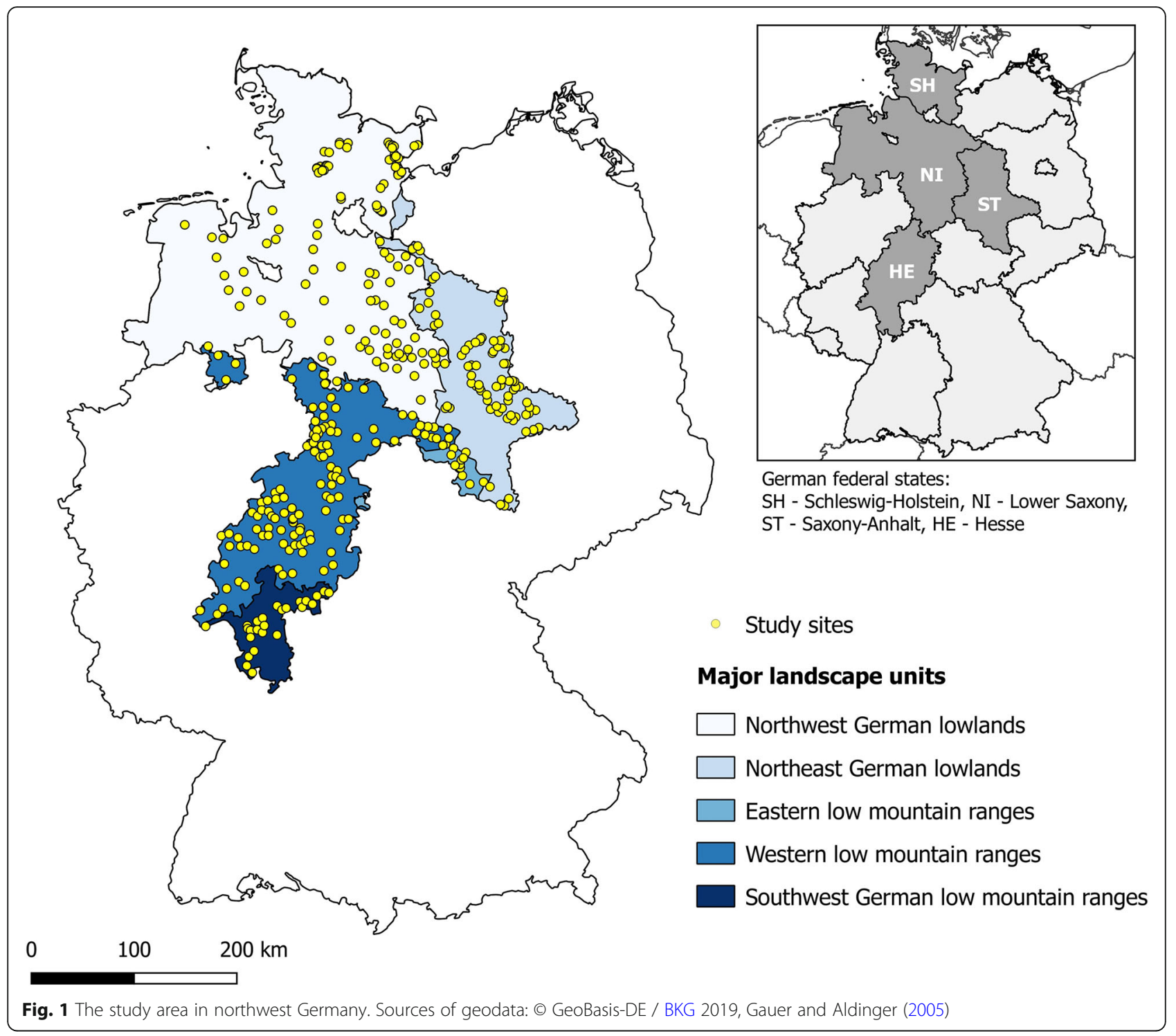

Aldinger 2005; Table 1). In the lowlands, deciduous ancient woodland sites (incl. oak forests) with a forest cover continuity of at least 200 years are rare and scattered, but in the low mountain ranges these valuable habitats can be found more frequently (Glaser and Hauke 2004). There are no woodlands completely unaffected by long-term human activity, and particularly the oak forests were shaped and maintained by centurylong multi-purpose management (Hesmer and Schroeder 1963; Zacharias 1996; Hase 1997). In present times, all of the four state forest enterprises considered in this study have implemented close-to-nature forestry in their forest management schemes. Their management targets follow the "German model" of integrative

Table 1 Woodland cover in the study area

\begin{tabular}{|c|c|c|c|c|}
\hline Federal state & $\begin{array}{l}\text { Forest cover } \\
(\text { ha) }\end{array}$ & $\begin{array}{l}\text { Forest cover } \\
(\%)^{\mathrm{a}}\end{array}$ & $\begin{array}{l}\text { Stocking type "oak" (\%) in the total forest } \\
\text { area }\end{array}$ & $\begin{array}{l}\text { Deciduous ancient woodland }(\%)^{\mathrm{b}} \text { in the total } \\
\text { forest area }\end{array}$ \\
\hline Schleswig-Holstein & 173,412 & 11 & 13 & 34 \\
\hline Lower Saxony & $1,204,591$ & 25 & 11 & 20 \\
\hline Saxony-Anhalt & 532,481 & 26 & 12 & 20 \\
\hline Hesse & 894,180 & 42 & 10 & 44 \\
\hline
\end{tabular}


multifunctional forest management, see Borrass et al. (2017) for a closer description of the underlying management objectives.

\section{Selection of the study sites Compiling young oak stand data}

Three types of young oak stands were extracted from the state forest inventory databases of the federal states Lower Saxony, Saxony-Anhalt, Hesse and SchleswigHolstein. First, all stands with young ( $\leq 20$ years) pedunculate oak (Quercus robur) or sessile oak (Q. petraea) as the dominant tree species. The designation of the age threshold was based on silvicultural considerations: During the first 20 years of stand development, young oaks become established in the stand. In this period the decisive measures and processes take place that are crucial for the success or failure of oak regeneration (Leibundgut 1978; Ammann 2013). The reference date for setting the tree age was 1 January 2016. Second, stands that were listed as yet unstocked at the publication date of the relevant management plan, but where afforestation with oak was planned were also included. This was done since forest inventories, which are the basis of forests management plans in the considered state forest enterprises, are conducted only once in a decade. For example, if a forest management plan from 2008 set the afforestation of a certain stand with oaks for 2009, this stand was included in our analysis with a tree age of seven years. Third, stands with established oak regeneration under the canopy of mature oaks were considered. In each case, the smallest forest area unit (e.g., forest compartment) of the respective forest inventory was used as spatial reference. Since 1) the silvicultural separation of the two oak species is becoming increasingly questionable (Lüpke 1998), 2) both species often occur mixed together, and 3) forest inventory data does not always specify the species affiliation correctly, we did not separate between $Q$. robur and $Q$. petraea in our analyses.

\section{Excluding scattered study sites}

The total dataset of 4252 young oak stands was reduced to those young oak stands with at least 20 old ( $\geq 150$ years) oak stands within a radius of $10 \mathrm{~km}$. By doing this, the selection of scattered, fragmented or untypical oak stands within the landscape matrix was avoided. Following this definition, 2494 young oak stands were included in the following analyses, comprising 988 stands in Lower Saxony, 983 stands in Saxony-Anhalt, 449 stands in Hesse and 74 stands in Schleswig-Holstein. The number of excluded young oak stands amounted to 978 stands in Lower Saxony, 354 stands in Saxony-Anhalt, 170 stands in Hesse and 256 stands in SchleswigHolstein.

\section{Grouping according to preceding land-use types}

After extensive investigation on stand history, the young oak stands were separated into two groups, A and B, according to the preceding land-use types:

A: Oak stands succeeding oak stands (established by seeding, planting or natural regeneration);

B: Oak stands not succeeding oak stands (e.g., conversion of conifer stands or afforestation of agricultural fields by planting or seeding).

\section{Spatially optimal selection of study sites}

Based on the two groups of young oak stands, the selection of study sites was carried out using the function "cover.design" in the R library "fields" (Nychka et al. 2016), accounting for a spatially balanced distribution of the study sites. The sample size for each of the forestrich federal states Lower Saxony, Saxony-Anhalt and Hesse was set to 100 study sites, taking into account both good data reliability and practical resources, whereas merely 50 study sites were investigated in the forest-poor Schleswig-Holstein.

The study site selection was done in two steps. First, the set number of type A sites was selected for Lower Saxony, Saxony-Anhalt and Hesse. This number included at least 50 type A sites in each federal state. Taking into account these fixed study sites in the further analysis, the second set of type B sites (difference between the number of type A sites and 100) was determined. For Schleswig-Holstein, the whole dataset contained only three type A sites, which were all selected.

\section{Data collection and field measurements}

For all 350 selected study sites (Fig. 1), we extracted detailed stand data from the forest inventory databases. In 2016 (July-November) and 2017 (July-October), all study sites were visited by skilled forest engineers. A total of 295 study sites appeared to be suited for further inventory and analysis, while 65 study sites had to be excluded for different reasons: for example, planned afforestation with oak had not been realized yet or changed forest planning meant that tree species other than oak were destined to be the main tree species. The 295 suitable study sites were inventoried by the field experts according to a specially developed procedure.

Our sampling procedure was aimed at both collecting sufficient data and ensuring an efficient work progress with regard to the high sample size in a large area. Factors that have been regarded as crucial for the success or failure of oak regeneration (Table 2) were included in the inventory procedure or extracted from the forest inventory databases. The climate quotient $Q$ (after Ellenberg) characterizes the natural competiveness of beech. Only where $Q$ is above 30 is beech completely absent or 
Table 2 Considered ecological and silvicultural factors

\begin{tabular}{|c|c|c|c|c|}
\hline \multicolumn{2}{|c|}{ Ecological and silvicultural factors } & \multirow{2}{*}{$\begin{array}{l}\text { Data source } \\
\text { Field inventory }\end{array}$} & \multirow{2}{*}{$\begin{array}{l}\text { Data type } \\
\text { See section "Data analysis in a } \\
\text { three-step success model" }\end{array}$} & \multirow{2}{*}{$\begin{array}{l}\text { References } \\
\text { Ammer and Dingel 1997; Wagner and Röker 2000; } \\
\text { Ligot et al. } 2013\end{array}$} \\
\hline $\begin{array}{l}\text { Ecological } \\
\text { factors }\end{array}$ & $\begin{array}{l}\text { Competition by other tree } \\
\text { species }\end{array}$ & & & \\
\hline & $\begin{array}{l}\text { Competitive vegetation (weeds, } \\
\text { grass, bracken) }\end{array}$ & Field inventory & Numerical & $\begin{array}{l}\text { Humphrey and Swaine 1997; Leonardsson et al. } \\
\text { 2015; Jensen and Löf } 2017\end{array}$ \\
\hline & $\begin{array}{l}\text { Shrub competition (bramble, } \\
\text { raspberry) }\end{array}$ & Field inventory & Numerical & Harmer et al. 2005; Jensen and Löf 2017 \\
\hline & $\begin{array}{l}\text { Canopy layer cover (proxy for } \\
\text { light availability) }\end{array}$ & Field inventory & Numerical & Hauskeller-Bullerjahn 1997; Ostrogović et al. 2010 \\
\hline & Water supply status & Forest inventory database & Nominal & Hauskeller-Bullerjahn 1997; Schmidt 2000 \\
\hline & Nutrient supply status & Forest inventory database & Ordinal & Hauskeller-Bullerjahn 1997; Schmidt 2000 \\
\hline & Lowland or low mountain range & Forest inventory database & Binary & Leuschner and Ellenberg 2017 \\
\hline & $\begin{array}{l}\text { Climate quotient Q (after } \\
\text { Ellenberg) }\end{array}$ & $\begin{array}{l}\text { German Meteorological } \\
\text { Service (DWD) }\end{array}$ & Numerical & Leuschner and Ellenberg 2017 \\
\hline \multirow{7}{*}{$\begin{array}{l}\text { Silvicultural } \\
\text { factors }\end{array}$} & Stand age & Forest inventory database & Numerical & Annighöfer et al. 2015 \\
\hline & Fencing & Field inventory & Binary & Annighöfer et al. 2015; Leonardsson et al. 2015 \\
\hline & Preceding land-use type & Forest inventory database & Binary & Valtinat et al. 2008 \\
\hline & Regeneration method & $\begin{array}{l}\text { Forest inventory database } \\
\text { / field inventory }\end{array}$ & Nominal & $\begin{array}{l}\text { Burckhardt 1870; Solymos 1993; Struck 1999; Drößler } \\
\text { et al. 2012; Kohler et al. } 2015\end{array}$ \\
\hline & Stand size & Forest inventory database & Numerical & Březina and Dobrovolný 2011 \\
\hline & Site preparation & Field inventory & Binary & Burckhardt 1870; Löf et al. 2006 \\
\hline & $\begin{array}{l}\text { Tending of young growth / pre- } \\
\text { commercial thinning }\end{array}$ & Field inventory & Binary & Leibundgut 1978 \\
\hline
\end{tabular}

grows poorly (Leuschner and Ellenberg 2017). We calculated $Q$ for each study site as a mean value for the time period 1981-2010, using data provided by the German National Meteorological Service (DWD):

$$
Q=\frac{T_{\text {July }} \times 1,000}{P_{\text {year }}}
$$

where $T_{\text {July }}$ is the average July temperature $\left({ }^{\circ} \mathrm{C}\right)$ and $P_{\text {year }}$ is the average yearly precipitation $(\mathrm{mm})$ in the time period 1981-2010.

In the field, factors such as fencing, site preparation or the tending of young growth were assessed with binary (yes/no) variables, while the mean percentage covers of the canopy layer, competitive vegetation (weeds, grass, shrubs, and bracken) and tree regeneration (per tree species) were visually estimated on the stand level at each study site. To calculate the initial numbers of planted oaks in artificially regenerated stands, the original planting schemes were evaluated. In particular, the field experts were requested to evaluate the regeneration success (yes/no) of each inventoried oak stand, including planned secondary tree species. This was done with reference to the forest development types described in the forest planning documents. A descriptive overview of the considered ecological and silvicultural factors and their characteristics with regard to the 295 study sites is given in Table 3.

In order to gather data on the density and height of young oaks and secondary tree species, six-tree samples (following Prodan 1968; Ko et al. 1969) were taken on each study site. Three sampling plots per study site were placed in such a manner that they represented the oak regeneration conditions of the study site sufficiently (in the sense of "pars pro toto"). In order to get reliable results, the field experts were trained in this regard to achieve consistent positioning of the three sampling plots within stands of varying size. Every six-tree sample included the measurement (tree heights and distance of the 6th tree from the plot center) and was performed separately for three predefined groups of young trees:

1) Oaks (Quercus robur, Q. petraea) as the target tree species.

2) Tree species that were planned as secondary tree species (max. three different tree species), e.g. European beech (Fagus sylvatica), hornbeam (Carpinus betulus), sycamore maple (Acer pseudoplatanus), small-leaved lime (Tilia cordata).

3) All other secondary tree species, particularly spontaneously regenerated silver birch (Betula pendula), willows (Salix spp.), rowan (Sorbus aucuparia), the neophytic black cherry (Prunus serotina), and conifers, such as Norway spruce (Picea abies) and Scots pine (Pinus sylvestris).

With regard to groups 2 and 3, we considered tree individuals that were comparable in height and age classes to the oaks in group 1. Only living trees were measured. 
Table 3 Silvicultural and ecological characteristics of the analyzed 295 study sites

\begin{tabular}{|c|c|c|c|c|}
\hline \multirow[t]{2}{*}{ Factors } & \multicolumn{4}{|c|}{ Number of study sites / values } \\
\hline & Yes & \multicolumn{3}{|l|}{ No } \\
\hline Forest development goal reached (expert opinion) & 163 & \multicolumn{3}{|l|}{132} \\
\hline Tillage and mounding & 104 & \multicolumn{3}{|l|}{191} \\
\hline Young growth tending/pre-commercial thinning & 199 & \multicolumn{3}{|l|}{96} \\
\hline Fencing & 245 & \multicolumn{3}{|l|}{50} \\
\hline Presence of canopy trees & 118 & \multicolumn{3}{|l|}{177} \\
\hline \multirow[t]{2}{*}{ Preceding land-use type } & Oak stand & \multicolumn{3}{|l|}{ Not oak stand } \\
\hline & 134 & \multicolumn{3}{|l|}{161} \\
\hline \multirow[t]{2}{*}{ Landscape context } & Low mountain range & \multicolumn{3}{|l|}{ Lowland } \\
\hline & 122 & \multicolumn{3}{|l|}{173} \\
\hline \multirow[t]{2}{*}{ Regeneration method } & Natural regeneration & Planting & Natural regeneration and planting & Seeding \\
\hline & 11 & 257 & 22 & 5 \\
\hline \multirow[t]{2}{*}{ Water supply status } & Dry soils & Fresh soils & Periodically moist/wet soils & Moist/wet soils \\
\hline & 59 & 121 & 72 & 43 \\
\hline \multirow[t]{3}{*}{ Nutrient supply status } & Eutrophic soils & Mesotrophic soils & Oligotrophic soils & \\
\hline & 45 & 230 & 20 & \\
\hline & Minimum & Mean & Maximum & \\
\hline Stand size (ha) & 0.1 & 1.8 & 17 & \\
\hline Stand age (years) & 2 & 12.7 & 20 & \\
\hline Canopy layer cover (\%) & 0 & 9.5 & 85 & \\
\hline Cover of competitive weeds (\%) & 0 & 1.1 & 100 & \\
\hline Cover of competitive grass (\%) & 0 & 19.0 & 100 & \\
\hline Cover of competitive bracken (\%) & 0 & 1.8 & 100 & \\
\hline Cover of competitive shrubs (\%) & 0 & 12.4 & 100 & \\
\hline
\end{tabular}

\section{Data analysis in a three-step success model}

\section{Six-tree samples and calculating competition intensity}

With respect to 1) each six-tree sample per study site and 2) to the three predefined groups of young trees, the mean tree heights and the numbers of trees per ha $\left(\mathrm{N} \cdot \mathrm{ha}^{-1}\right.$ ) were calculated (cf. Kramer and Akça 2008):

$$
\text { numbers of trees per ha }=\frac{10,000}{\pi a_{6}^{2}}
$$

where $a_{6}(\mathrm{~m})$ is the distance between the plot center and the 6 th tree.

For each of the three six-tree samples per study site, we then calculated whether the oaks (group 1) were exposed to competitive pressure from the secondary tree species (groups 2 and 3) or not. By our definition, relevant competitive pressure existed when

- the secondary tree species had a higher tree density $\left(\mathrm{N} \cdot \mathrm{ha}^{-1}\right)$ at a mean plant height that reached at least $3 / 4$ of the mean oak height (cf. Ammer and Dingel 1997; Otto et al. 2009),
- or the secondary tree species reached - when they were taller than the oaks - a tree density $\left(\mathrm{N} \cdot \mathrm{ha}^{-1}\right)$ that matched at least $20 \%$ of the oak density $\left(\mathrm{N} \cdot \mathrm{ha}^{-1}\right.$ ) (cf. Ammer and Dingel 1997; Ligot et al. 2013).

In cases with relevant competitive pressure a " 1 " was assigned, in cases with no relevant competitive pressure a "0". By summing up the three competition numbers calculated from the three six-tree samples per study site, we determined a categorical total competition index for each study site that ranged from 0 to 3 :

0 : no competition.

1: low competition.

2: medium competition.

3: high competition.

\section{Determining the success of oak regeneration}

To determine the success of oak regeneration in each study site, we developed a theoretical model with the target values "successful" or "unsuccessful". For this purpose, parameters calculated from the six-tree samples $\left(\mathrm{N} \cdot \mathrm{ha}^{-1}\right.$, mean tree heights) were combined with forest inventory data (age of the young oaks) and field data (initial plant numbers). 
To be considered a successfully regenerated oak stand, the oak regrowth of a certain study site had to meet two conditions (Figs. 2 and 3):

1) A best-fit curve (conditional median) was fitted to the age-height correlation data of oak from all study sites. All data points ( $\triangleq$ study sites) above this curve indicated successfully regenerated oak stands

(Fig. 2). A separate test analysis of study sites with eutrophic, mesotrophic or oligotrophic nutrient status revealed no relevant differences between the best-fit curves of these three groups.

2) A linear best-fit curve was fitted to the age-density correlation data of oak from all study sites. All data points ( $\triangleq$ study sites) above this curve indicated successfully regenerated oak stands, when no initial plant numbers (N.ha ${ }^{-1}$ ) were available (Fig. 3, categories 1 and 2). If the initial plant number of a study site was available, a separate best-fit curve was determined for this site (Fig. 3, categories 3 and 4). This curve intersected the individual initial plant number $\left(\mathrm{N} \cdot \mathrm{ha}^{-1}\right)$ at age 0 and a minimum target plant number of 2000 plants.ha $^{-1}$ at age 20 (cf. Leibundgut 1978; Hochbichler and Krapfenbauer 1988; Noack 2013). The choice of this minimum target plant number was very conservative and took into account that secondary tree species frequently occurred. If the oak plant number $\left(\mathrm{N} \cdot \mathrm{ha}^{-1}\right)$ in the study site under consideration exceeded the individual best-fit curve at the time of the field inventory, then this study site was considered to be successfully regenerated (Fig. 3, category 4). We are aware that mixing input-weighted and input-unweighted density-age relations is a little inconsistent, but in this case we regard it as practicable and statistically tolerable.

\section{Modeling the success factors of oak regeneration}

We used a Generalized Structured Additive Regression (STAR) model - well-established frameworks of Generalized Linear Models (GLM) and Generalized Additive Models (GAM) are considered as special cases of STAR models - to relate the potential predictors (see Table 2) to the binary scaled outcome "success of oak regeneration". The STAR model class provides a maximally flexible framework for modeling of (possible) nonlinear effects of continuously scaled predictors, while also allowing for modeling effects of categorically scaled predictors.

Here, for study location index $i=1, \ldots, 295$, the success of the oak regeneration variable $y_{i} \in\{0$ : failed; 1 : successful $\}$ is Bernoulli distributed, $y_{i} \sim B\left(p_{i}\right)$, with the conditional expectation:

$$
E\left(y_{i} \mid x_{1 i}, \ldots, x_{k i}\right)=\operatorname{Pr}\left(y_{i}=1 \mid x_{1 i}, \ldots, x_{k i}\right)=p_{i}
$$

which is the probability of having successful oak regeneration as an outcome, conditional on predictor values $x_{1 i}, \ldots, x_{k i}$. Effects of covariates were included as regression coefficients $\beta_{j}=\left(\beta_{j 1}, \ldots, \beta_{j k_{j}}\right)^{\top}, j=1, \ldots, k$, where each sub vector $\beta_{j}$ united regression coefficients of covariate $x_{j}$. Non-linear effects were modeled via penalized spline estimation, contributing several coefficients per covariate (i.e. $k_{j}>1$ ), which were collected in covariate specific vectors $x_{i, j}=\left(x_{i, j, 1}, \ldots, x_{i, j, k_{j}}\right)^{\top}$, as a splines basis is constituted of several basis functions. Binary

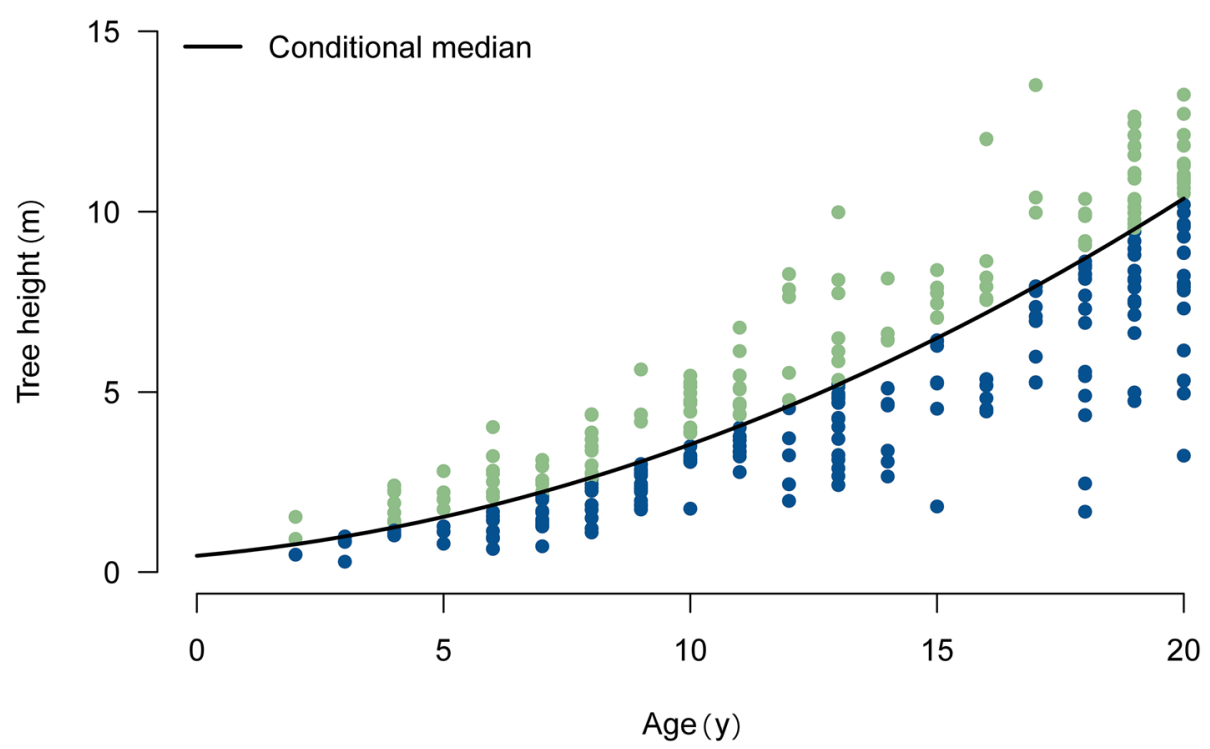

Fig. 2 Age-height correlation data of oak from 295 study sites. Green dots: positive rating, blue dots: negative rating 

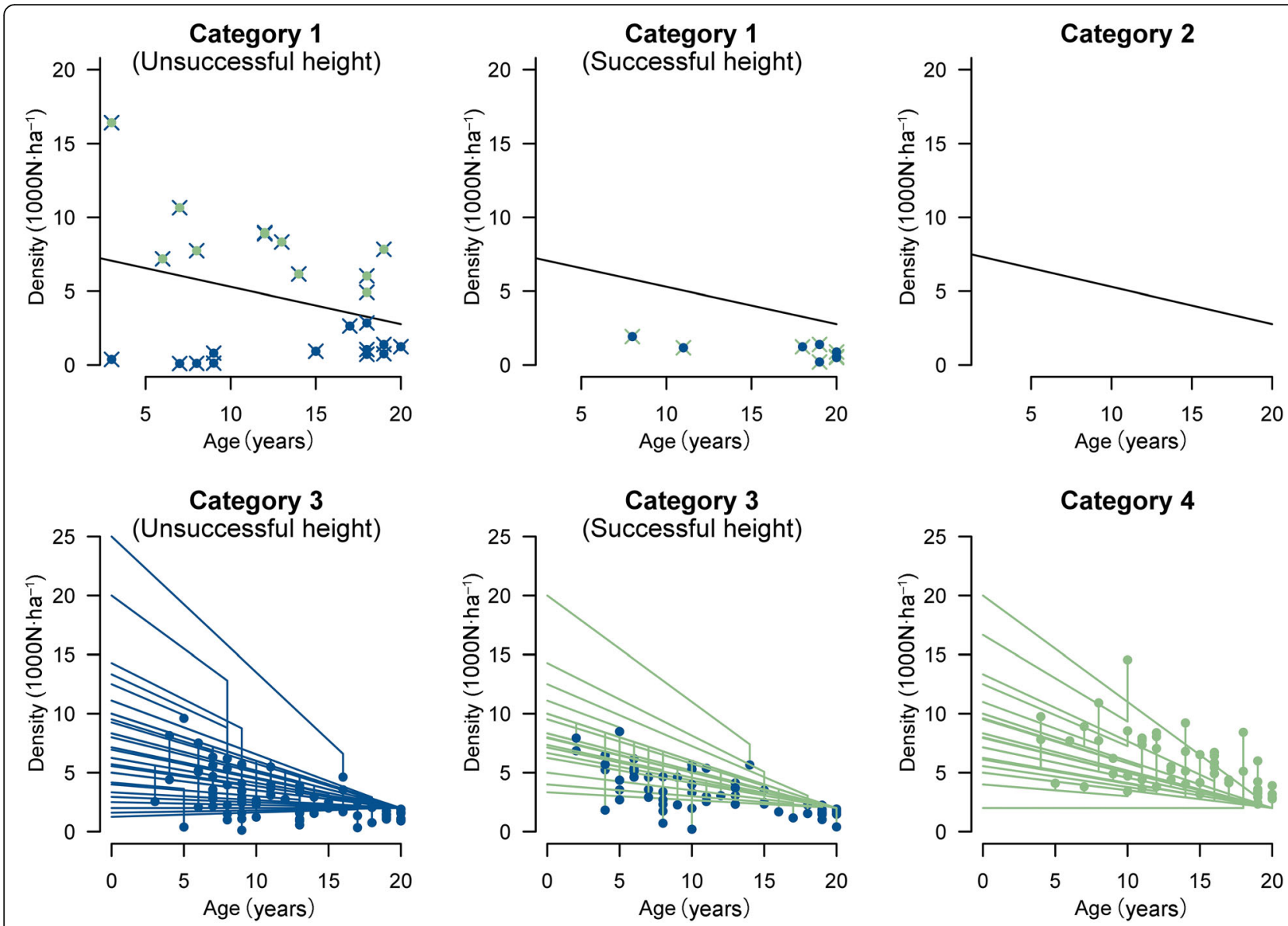

Fig. 3 Age-density correlation data of oak from 295 study sites. To be considered a successfully regenerated oak stand, the oak regrowth of a certain study site had to meet predefined conditions. Green: positive rating, blue: negative rating. The color of the crosses refers to the rating in Fig. 2. Category 1 (unsuccessful height, see Fig. 2) $=25$ study sites, Category 1 (successful height, see Fig. 2) = 8 study sites, Category 2 (successfully regenerated) $=0$ study sites, Category 3 (unsuccessful height, see Fig. 2) $=152$ study sites, Category 3 (successful height, see Fig. 2) = 64 study sites, Category 4 (successfully regenerated) $=56$ study sites

covariates contributed only one coefficient, i.e. $k_{j}=1$. Products of covariate values and regression coefficients formed individual, i.e. study location index specific, linear predictor values:

$$
\eta_{i}=\beta_{0}+\sum_{j=1}^{k} x_{i, j}^{\top} \beta_{j}
$$

where the relationship between $p_{i}$ and the linear predictor $\eta_{i}$ is provided by the logit link function:

$$
p_{i}=\frac{\exp \left(\eta_{i}\right)}{1+\exp \left(\eta_{i}\right)}
$$

For estimations of this model and the respective coefficients, we relied on a Bayesian estimation approach, with spike-and-slab priors provided by the $\mathrm{R}$ add-on package "spikeSlabGAM" (Scheipl et al. 2012) performing variable and model selection within the estimation process, thus providing valid inferences about the model constitution in such a scenario of uncertainty.

We use default priors (Scheipl 2011) and ran five independent chains with a length 10,000 samples from the full posterior, where the first 5000 samples were discarded (burn-in), and the remaining 5000 iterations were thinned by keeping only each fifth sample (Additional file 1).

For continuously scaled covariates, two model terms were constructed and included into the estimation algorithm by spikeSlabGAM as a result of non-linear effect decomposition into a linear part (denoted as lin) and the remaining non-linear deviation (denoted as $\mathrm{sm}$ ) from the linear part. Model terms for categorically scaled covariates were denoted as $f c t$.

Results of a spikeSlabGAM fit are best represented graphically by plotting marginal covariate effects. As summary numbers, Scheipl (2011) advocated relying on the percentage of sum of squares of the linear predictor 
(term importance $\pi$, can be seen as each model term's share of the amount of variability of $y$ explained by the model) and marginal term-wise posterior inclusion probabilities $\operatorname{Pr}$ (term $k$ in).

\section{Analysis of collinearity}

It appeared not to be directly clear, however, if and how strong our sample deviated from a balanced data set comparable to controllable experimental conditions. Thus, correlations between the influencing variables used in our modeling might occur, which make the estimated marginal effect correlations more difficult to interpret. This is referred to as the problem of (multi-) collinearity (Fahrmeir et al. 2013). As the effect of the factor tree competition showed the strongest influence, the potential for making a too direct causal classification of the effect was greatest here. In an analysis of (multi) collinearity, one usually uses the coefficient of determination $R^{2}$ of a linear regression - with the influencing quantity under suspicion as the response variable against all other influences as influence quantities - as basis for the Variance Inflation Factor (VIF). Since the factor tree competition was categorical, we could not follow this path completely, but by use of a regression model for an ordered categorical response (implemented in R add-on package "mgcv" (Wood 2011) as family "ocat") we came this goal at least one step closer (Additional file 1).

\section{Results}

Following our theoretical model approach to determine the success of oak regeneration, 56 out of 295 study sites ( $\hat{=} 19 \%$ ) could be referred to as successfully regenerated young oak stands. The regeneration success evaluation by the field experts, which was done with reference to the forest development types described in the forest planning documents, identified 163 out of 295 study sites $(\hat{=} 55 \%)$ as successfully regenerated (Table 4$)$.

When referring to the success factors of oak regeneration, Table 5 shows the importance and inclusion probabilities for all model terms, while Fig. 4 displays marginal coefficient effect plots only for the eight most decisive model terms, as selected by highest values in Table 5.

Our modeling revealed that competitive pressure from the secondary tree species was clearly the most decisive success factor for oak regeneration: No competition or low competition by secondary tree species appeared to be particularly beneficial. With regard to the climate quotient, $Q$, factor values around 23 and 30 showed a connection with successful oak regeneration, while fencing and the absence of competitive vegetation (weeds, grass, bracken) also seemed to be beneficial. The coefficient effect plots of the remaining four decisive model terms did not allow for a meaningful interpretation of the factor values.

The subsequent (multi-) collinearity analysis of the factor tree competition revealed that, when we refer to stands with absent tree competition, these stands showed a tendency to be regenerated by planting. Furthermore, these stands tended to be characterized by young growth tending, low shrub competition, fencing, absent deer browsing, site preparation, smaller stand sizes, eutrophic soils, and by a location in the lowlands. The occurrence of competitive vegetation (weeds, grass, bracken) also tended to be an attribute of these stands (Figs. 5 and 6, Additional file 1).

\section{Discussion \\ Methodological aspects}

In order to effectively gather data on the density and height of young oaks and secondary tree species, six-tree samples, as a particular case of $k$-tree sampling (following Prodan 1968; Ko et al. 1969), were taken in the studied stands. In contrast to point sampling (Bitterlich sampling) or sampling with fixed-area plots, the number of included trees per unit is fixed in $k$-tree sampling (Kramer and Akça 2008). The substantial benefit of this method lies in the reduced field work effort and, hence, in the control of inventory costs. This applies in particular for assessing tree regeneration in cases when high stem densities are quite usual or measurement conditions turn out to be difficult, e.g. due to blackberry thickets.

Because of these practical advantages, $k$-tree sampling has been frequently applied in forest resource assessment (e.g., Sheil et al. 2003; Picard et al. 2005), but, on the other hand, it is not uncontested from the statistical point of view (e.g., Mandallaz 1995; Kleinn and Vilčko 2006). If the distance to the $k$-th tree is taken as the radius of the plot circle, the smallest possible circular area is defined where exactly $k$ trees occur. The crucial point now is that larger plots, with a radius marginally smaller

Table 4 Success of oak stand regeneration: comparison of the evaluation by field experts and the results of the theoretical model. $N=295$ study sites

\begin{tabular}{llll}
\hline & & Theoretical model & \\
\cline { 3 - 4 } & & Oak regeneration not successful & Oak regeneration successful \\
\hline Field expert evaluation & Forest development type not accomplished & 125 & 7 \\
& Forest development type accomplished & 114 & 49 \\
\hline
\end{tabular}


Table 5 Inclusion probabilities $\operatorname{Pr}$ (term $k$ in) and term importance $\pi$ for all model terms

\begin{tabular}{lll}
\hline & $\begin{array}{l}\operatorname{Pr}(\text { term } k \text { in) } \\
(\%)\end{array}$ & $\begin{array}{l}\text { Term importance } \pi \\
(\%)\end{array}$ \\
\hline fct (Tree competition) & 100 & 62.7 \\
sm (Climate quotient Q) & 89.3 & 6.6 \\
fct (Competitive vegetation) & 80.1 & 22 \\
fct (Fencing) & 34.6 & 7.9 \\
sm (Age of oak stand) & 14.3 & 0.2 \\
sm (Shrub competition) & 9.6 & 0.4 \\
sm (Stand size) & 3.6 & 0 \\
fct (Preceding land-use type) & 1.1 & 0 \\
fct (Regeneration method) & 0.3 & 0 \\
fct (Landscape type) & 0.3 & 0 \\
lin (Shrub competition) & 0.3 & 0 \\
lin (Canopy layer cover) & 0.3 & 0 \\
lin (Age of oak stand) & 0.3 & 0 \\
fct (Status of water supply) & 0.3 & 0 \\
fct (Status of nutrient supply) & 0.3 & 0 \\
sm (Canopy layer cover) & 0.3 & 0 \\
lin (Stand size) & 0.3 & 0 \\
fct (Browsing) & 0.3 & 0 \\
lin (Climate quotient Q) & 0.3 & 0 \\
fct (Young growth tending) & 0.3 & 0 \\
fct (Site preparation) & 0.3 & 0 \\
\hline & & 0 \\
\hline
\end{tabular}

than the distance of the $k$ th +1 tree, would also contain $k$ trees, resulting in lower density estimates (e.g., tree number). Furthermore, the omission of 'empty' plots in $k$-tree-sampling is problematic if the spatial tree distribution is not random but follows a clustered point pattern. Density estimators are then expected to be critically biased due to ignoring gaps (where density is zero). In the present study, however, this point is not critical because sampling locations for estimating regeneration density were not randomly distributed throughout the stands but were placed within the regeneration patches, in order to study competition patterns. Although there are several approaches to overcome the aforementioned methodological shortcomings of $k$-tree sampling (e.g., Kleinn and Vilčko 2006; Staupendahl 2008; Nothdurft et al. 2010), these solutions require both intensive and costly additional inventory effort and rather complex subsequent computations. For these reasons, we used the standard evaluation methods proposed by Prodan (1968) and accepted the potential inherent bias of $k$-tree sampling, which has been shown to be within a tolerable order of magnitude in some studies (Lessard et al. 1994; Staupendahl 2008).
In addition to the ecological and silvicultural factors that were surveyed in the sampling procedure of the present study, future applications of the presented approach could be advanced by considering the factors "costs" and "tree quality". With regard to the factor "tree quality", the categorical assessment of stem curvature (crookedness) could be easily carried out when measuring the oaks that are included in the six-tree samples (cf. Skrzyszewski and Pach 2015). The estimation of the costs arising up to the first 20 years of stand development, however, would require extensive investigations of accounting records.

\section{Silvicultural aspects}

According to our theoretical model, 19\% of the investigated study sites can be regarded as successfully regenerated young oak stands. We are aware that this proportion might appear surprisingly low for many forestry practitioners. However, due to the predefined conditions for the determination of successful study sites we made sure that the success factors of oak regeneration were modeled using solid reference data. When comparing the calculated success of oak regeneration with the regeneration success evaluated by expert opinion in the field, the latter amounted to 55\%. The difference of $36 \%$ can be explained by the fact that the field experts were requested to evaluate the regeneration success of the whole study site including planned secondary tree species. This was done with reference to the forest development types described in the forest planning documents. However, a success rate of $55 \%$ may also be regarded as low considering the high investment in the establishment of oak cultures.

The modeled success factors for oak regeneration provide important information with regard to the goal of making recommendations for measures that increase the success rate of oak forest regeneration. First of all, the results show that competition by secondary tree species is the most crucial factor, with no or low competition pressure being beneficial for the success of oak regeneration. This does not mean, however, that secondary tree species, particularly the early successional birches (Betula spp.) and willows (Salix spp.), are undesirable or not helpful for oak quality development. But thorough, mechanical young growth tending and pre-commercial thinning appear to be urgently necessary to regulate competition by these secondary tree species (Ammer and Dingel 1997). Our results also highlight the necessity to regulate competition by weeds, grass, and bracken by ecologically compatible measures and to install fences or intensify hunting to avoid deer browsing. We are aware that these insights have been expressed frequently since the beginnings of modern forestry (Fuchs 1824; Burckhardt 1870; Humphrey and Swaine 1997; 


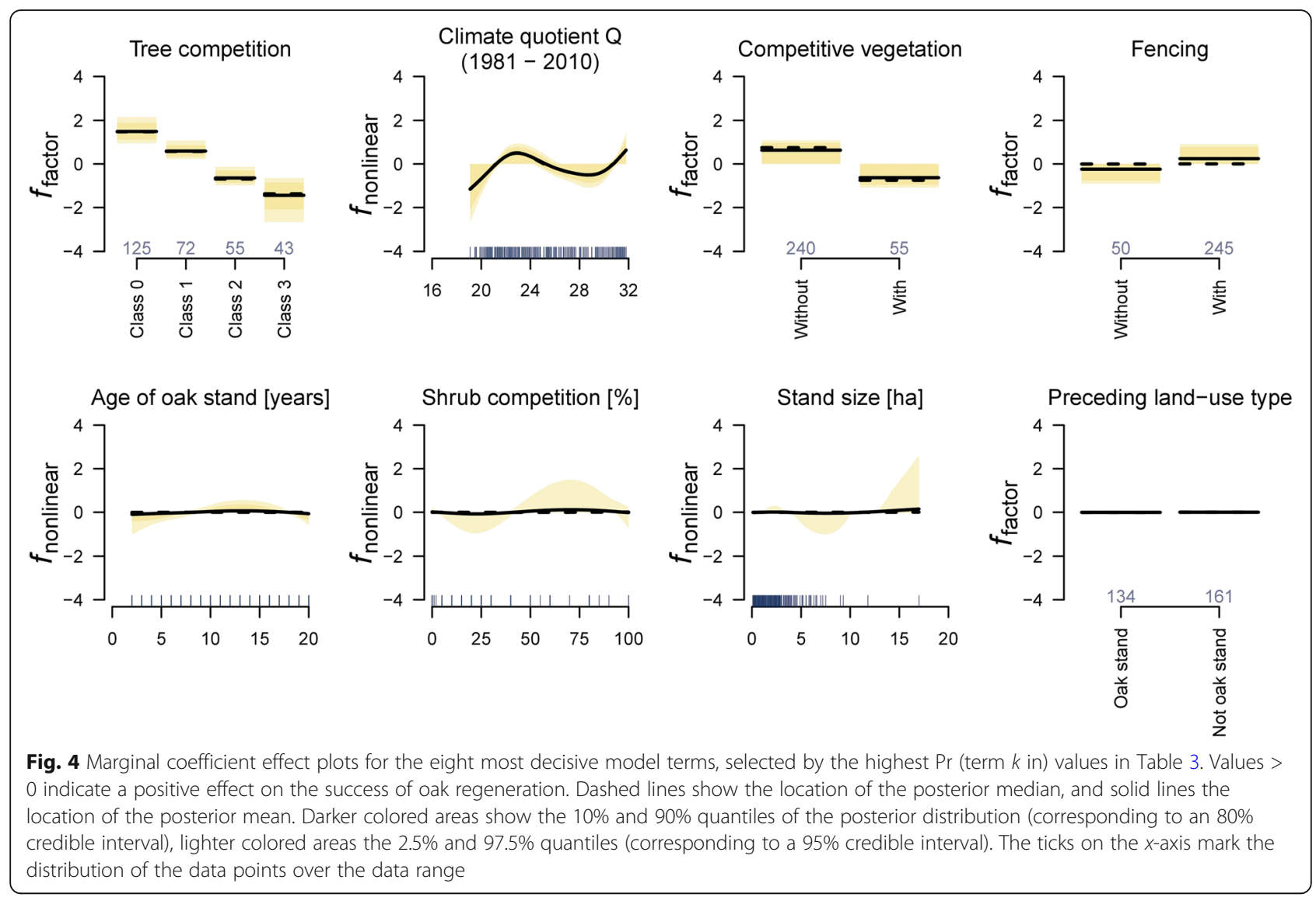

Leonardsson et al. 2015). Owing to economic constraints, the necessary silvicultural measures are, however, usually neglected. With regard to the Ellenberg climate quotient $Q$, we found a positive connection between factor values around 23 and 31 and successful oak regeneration. This correlation cannot be clearly explained and seems to be intercorrelated with other influence factors. The positive effect of $Q$ values larger than 30 , however, can be attributed to poorer growth of the strong competitor species beech in the respective regions (Ligot et al. 2013; Leuschner and Ellenberg 2017).

The closer analysis of the strong influencing factor tree competition revealed that this variable can be also regarded as an "umbrella factor". This means that several silvicultural and environmental factors are reflected in low and beneficial levels of tree competition. The silvicultural factors that appeared to be crucial in this regard, in particular young growth tending and fencing, have been discussed above and can be steered by careful silviculture. For site preparation, careful site management with minimal soil disturbance was advised within the framework of close-to-nature forestry. This is particularly true for ancient woodland sites with century-long soil genesis and occurrences of specialized animal and plant species (Schmidt et al. 2014; Winter et al. 2015;
Magura et al. 2015). The finding that the occurrence of competitive vegetation (weeds, grass, bracken) tended to be an attribute of stands where tree competition is absent can be related to increased growing space in the understory of these stands.

While young growth tending and pre-commercial thinning of regenerated oak stands clearly need more attention and implementation in practical forestry, forestry research has already addressed this topic in various studies and intense discussions. Views regarding the appropriate silvicultural treatment concepts for young oak stands differ widely however, and vary considerably even from region to region. The proposed treatments range from cautious (pre-commercial) thinning without an early, or at least permanent, selection of favored trees, to an early positive tree selection with subsequent strong promotion of a limited number of future crop trees (Hochbichler and Krapfenbauer 1988; Mosandl et al. 1991; Fleder 1994; Spellmann 2001; Dong et al. 2007; Spiecker 2007; Beinhofer 2010). Thus, an enhanced information exchange and discussion between practical forestry and forestry research appears to be urgently necessary. There may be, however, a publication bias towards studies that report successfully regenerated oak stands, whereas failed cases are possibly neglected (cf. 


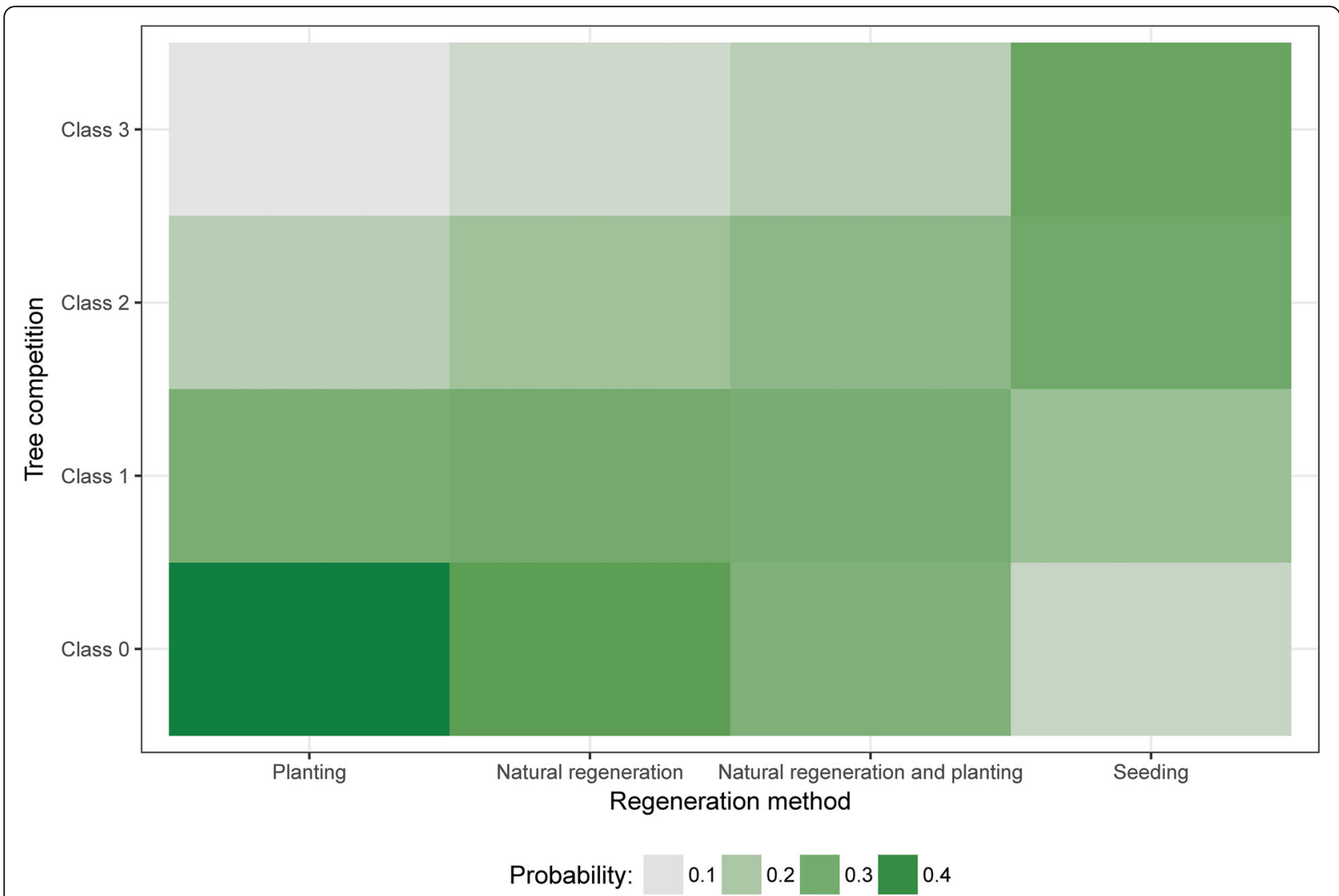

Fig. 5 Results of the (multi-) collinearity analysis of the factor "tree competition", attribute "regeneration method". See also Additional file 1 for further diagrams

Crouzeilles et al. 2016). The same may be true for oral reports from forestry practitioners when they discuss with their colleagues.

Considering the regeneration methods, (row) planting was by far (87\%) the most commonly used technique within our set of study sites. Natural regeneration, which is frequently recommended within the framework of close-to-nature forestry, played only a minor role (11\%), as did acorn seeding (2\%). However, natural regeneration and seeding of oaks is more commonly applied in southern and southwest Germany, where these techniques have a long tradition (Fleder 1994; Lüpke 2007; Mölder et al. 2017). In Scots pine forests, "seeding" of acorns by Eurasian jays (Garrulus glandarius) can provide options for oak regeneration, but, following a study conducted by Stähr (2008), the resulting oak stem qualities are low. Kohler et al. (2015), who conducted a review on the natural regeneration of sessile oak, pointed out the general feasibility of this technique but, due to several identified knowledge gaps, the authors regarded it as impossible to give general management recommendations. They advocated not to replace locally successful silvicultural methods by alternative techniques with uncertain outcome. With regard to planting schemes that minimize interspecific competition, the spatial separation of oak and admixed competitive shade-tolerant tree species (beech, hornbeam) of the same age might to be useful, especially when considering the effort required in young growth tending. However, these tree species can also act as trainer trees that improve oak quality. As Saha et al. (2012) highlighted, this is particularly true for oak group planting, a possible alternative to oak row planting. Lüpke (1998) stated that oaks should have a considerable age advantage over beeches and that the beeches should never originate from advanced regeneration.

When considering oak regeneration planning and silvicultural decision-making within a forest enterprise, we strongly recommend to initially evaluate the annual financial and personnel capacities for carrying out young growth tending or pre-commercial thinning and only then to decide on the extent of new oak cultures. Otherwise, there is a high risk of failed investments in initial oak regeneration. The limited availability of oak seedlings for planting can also be a strong reason for careful regeneration planning. For example, after severe storms 


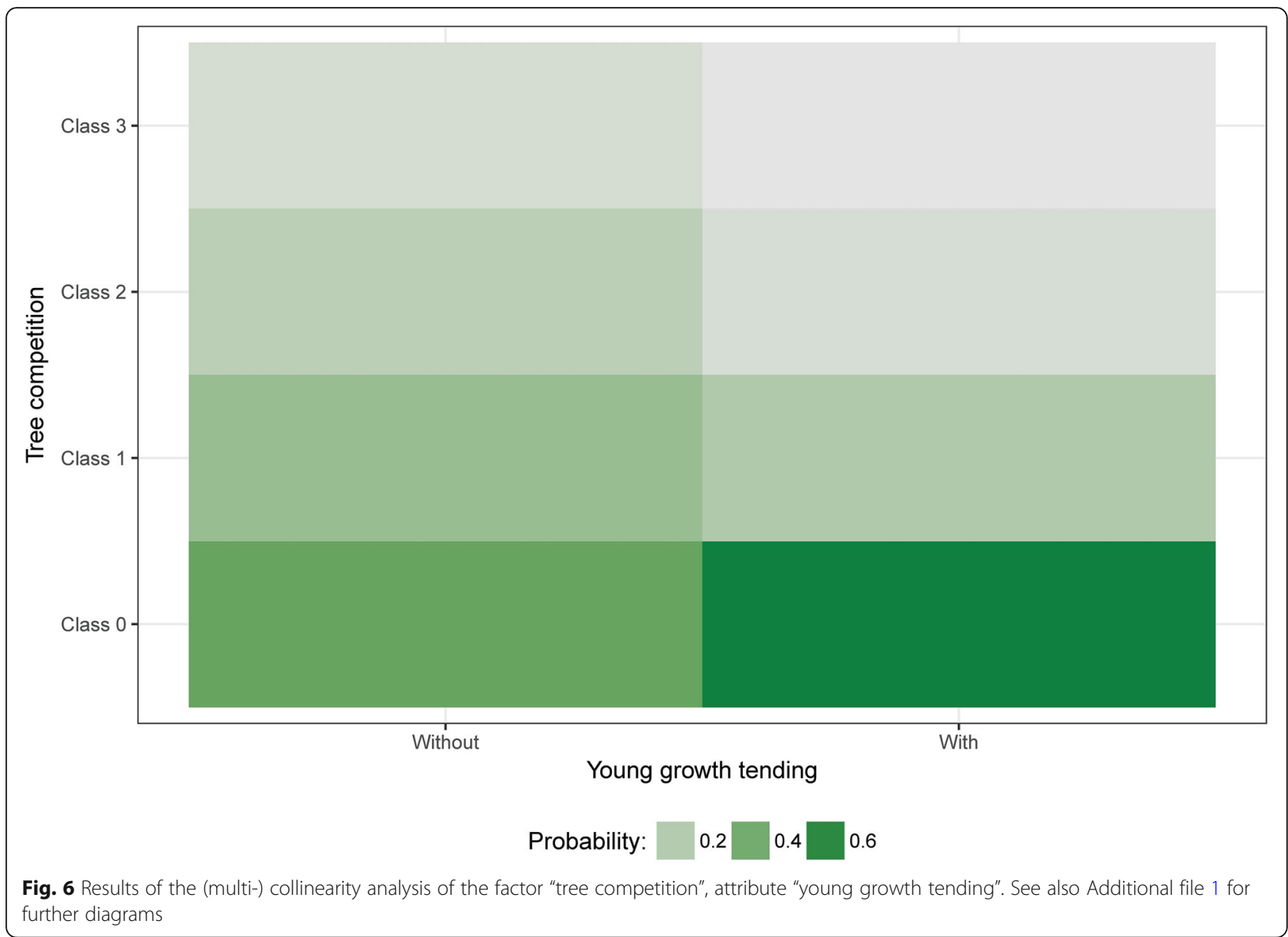

and subsequent bark beetle attacks a great shortage of oak seedlings from tree nurseries is to be expected, due to a heavy demand for plants for reforestation. The limited available plants should be used in a very thoughtful manner.

Careful and adaptive regeneration planning is also indispensable for the long-term maintenance of ecological continuity (Moore and Conroy 2006). Ecological continuity has been shown to be particularly important in oak forest ecosystems (Eliasson and Nilsson 2002; Bußler and Loy 2004; Pilskog et al. 2018; Mölder et al. 2019). Many saproxylic oak specialist species with low dispersal abilities are dependent on the permanent availability of dead wood and mature tree structures (Drobyshev et al. 2008; Vodka et al. 2009; Milberg et al. 2016). Therefore, in order to maintain "sustainability units" of ecological continuity in ancient woodlands, oak forest regeneration measures ought to take place either in close vicinity to old oak stands or directly in these stands (Mölder et al. 2019). Methods of spatial forest planning (Baskent and Keles 2005) and systematic conservation planning (Moilanen et al. 2009) can provide important tools to identify priority sites for oak forest regeneration. In this regard, forest planning goals that consider the consequences of climate change have also to be implicated (Schelhaas et al. 2015; Böckmann et al. 2019), as do requirements resulting from the European Habitats Directive (Natura 2000; ML and MU 2018).

In times of widespread close-to-nature-forestry, the retention of oak habitat trees is commonly implemented in silvicultural programs (Borrass et al. 2017; Mölder et al. 2019). When considering current habitat tree density, Bütler et al. (2013) recommended to maintain a level of at least 5 to 10 trees per hectare and to combine dispersed and aggregated retention ("variable retention") to minimize wind damage. In order to safeguard both ecological continuity and economic demands, it is also important to secure a sufficient number of young oak trees. In accordance with Leibundgut (1978), we recommend at least 2000 oaks per hectare at a stand age of 20 years. Already Wilbrand (1893), who called for the protection of old oaks for aesthetic reasons, highlighted the importance of a high number of younger oaks to ensure a small number of ancient trees in the future. Model analyses conducted by Drobyshev et al. (2008) indicated that under current oak mortality rates the long-term 
maintenance of 20 trees older than 200 years per hectare would theoretically require an input rate of 1 to 5 trees per year and hectare into the 100-150 years age class.

\section{Conclusions}

We developed an efficient and sufficiently accurate sampling scheme for supra-regional forest regrowth inventories and applied it to young oak stands. The collected data were analyzed in a three-step success model aimed at identifying the crucial success factors for high-quality oak forest regeneration. Our modeling revealed that competitive pressure from the secondary tree species was clearly the most decisive success factor: No competition or low competition by secondary tree species appeared to be particularly beneficial for the success of oak regeneration. Fencing and the absence of competitive vegetation (weeds, grass, bracken) also seemed to be beneficial factors. Therefore, trusting in biological automation was found to be mostly useless with regard to oak forest regeneration. To efficiently organize oak regeneration planning and silvicultural decision-making within a forest enterprise, it is strongly recommended to initially evaluate the annual financial and personnel capacities for carrying out young growth tending or precommercial thinning and only then to decide on the extent of new oak cultures. To secure the long-term ecological continuity in oak forests, oak regeneration should preferably take place within the close vicinity of old oak stands or directly in them. The retention of habitat trees is urgently advised.

\section{Additional file}

Additional file 1. Utilized estimation calls and results of the (multi-) collinearity analysis of the factor "tree competition".

\author{
Abbreviations \\ GAM: Generalized Additive Model; GLM: Generalized Linear Model; N.ha \\ 1: Number of trees per hectare; Q: Climate quotient after Ellenberg; \\ STAR: Generalized Structured Additive Regression model
}

\section{Acknowledgments}

Most of all, we thank the very sedulous field experts Carolin Schwarze, Maria Spletter, Maximilian Scheel, Malte Dicke, Lars Neumeyer and Werner Hiege. Hermann Spellmann provided very helpful input and encouragement in the conception, design and implementation of this study. We are grateful to the state forest administrations of Lower Saxony, Saxony-Anhalt, Hesse and Schleswig-Holstein for providing forest inventory data. Furthermore, we are thankful to Robert Larkin for proofreading. We are also indebted to two anonymous reviewers for suggestions that have greatly improved the paper.

\section{Authors' contributions}

$H R, R N, E S$ and AM planned and conducted the study. JS and AM conducted data processing and management. ES and HSR executed the statistical analyses. AM, CF and HSR wrote the majority of the manuscript. All authors read and approved the final manuscript.

\section{Funding}

We gratefully acknowledge the funding of the project "QuerCon - Longterm conservation of ecological continuity in oak forests" (Grant number 32694) by the German Federal Environmental Foundation (DBU).

\section{Availability of data and materials}

The field datasets that were collected and analyzed during the current study are available from the corresponding author on reasonable request. The forest inventory data that support the findings of this study are available from the Northwest German Forest Research Institute, but restrictions apply to the availability of these data, which were used under license for the current study, and so are not publicly available. Data are however available from the authors upon reasonable request and with permission of the state forest administrations of the federal states Lower Saxony, Saxony-Anhalt, Hesse and Schleswig-Holstein.

Ethics approval and consent to participate

Not applicable.

\section{Consent for publication}

Not applicable.

\section{Competing interests}

The authors declare that they have no competing interests.

\section{Author details}

${ }^{1}$ Department A (Forest Growth), Northwest German Forest Research Institute (NW-FVA), Grätzelstraße 2, D-37079 Göttingen, Germany. ${ }^{2}$ Lower Saxony State Forests (NLF), Bad Lauterberg District Office, Kupferhütte 2, D-37431 Bad Lauterberg, Germany.

Received: 13 March 2019 Accepted: 28 October 2019

Published online: 20 November 2019

\section{References}

Ammann P (2013) Erfolg der Jungwaldpflege im Schweizer Mittelland? Analyse und Folgerungen (Essay) (Is young growth tending successful in the Swiss plateau region? Analysis and implications (essay)). Schweiz Z Forstwes 164: 262-270. https://doi.org/10.3188/szf.2013.0262

Ammer C, Dingel C (1997) Untersuchungen über den Einfluß starker Weichlaubholzkonkurrenz auf das Wachstum und die Qualität junger Stieleichen (Investigating the effects of strong competition by inferior tree species on growth and quality of young European oaks). Forstw Cbl 116: 346-358. https://doi.org/10.1007/BF02766910

Annighöfer P, Beckschäfer P, Vor T, Ammer C (2015) Regeneration patterns of European oak species (Quercus petraea (Matt.) Liebl., Quercus robur L.) in dependence of environment and neighborhood. PLoS One 10:e0134935. https://doi.org/10.1371/journal.pone.0134935

Anonymus (1869) Der Spessart und seine forstliche Bewirthschaftung (Forest management in the Spessart mountains). Kgl. Hofbuchdruckerei von Dr. C. Wolf und Sohn, München

Baskent EZ, Keles S (2005) Spatial forest planning: a review. Ecol Model 188:145173. https://doi.org/10.1016/j.ecolmodel.2005.01.059

Beinhofer B (2010) Comparing the financial performance of traditionally managed beech and oak stands with roomy established and pruned stands. Eur J Forest Res 129:175-187. https://doi.org/10.1007/s10342-009-0311-5

Birkedal M, Fischer A, Karlsson M, Löf M, Madsen P (2009) Rodent impact on establishment of direct-seeded Fagus sylvatica, Quercus robur and Quercus petraea on forest land. Scand J For Res 24:298-307. https://doi.org/10.1080/ 02827580903055125

Böckmann T, Hansen J, Hauskeller-Bullerjahn K, Jensen T, Nagel J, Nagel R-V, Overbeck M, Pampe A, Petereit-Bitter A, Schmidt M, Schröder M, Schulz C, Spellmann H, Stüber V, Sutmöller J, Wollborn P (2019) Klimaangepasste Baumartenwahl in den Niedersächsischen Landesforsten (Climate-adapted tree species choice in the state forests of Lower Saxony). Aus dem Walde 61: $1-141$

Borrass L, Kleinschmit D, Winkel G (2017) The "German model" of integrative multifunctional forest management - analysing the emergence and political evolution of a forest management concept. For Policy Econ 77:16-23. https://doi.org/10.1016/j.forpol.2016.06.028 
Brändle M, Brandl R (2001) Species richness of insects and mites on trees: expanding Southwood. J Anim Ecol 70:491-504. https://doi.org/10.1046/j. 1365-2656.2001.00506.x

Brang P, Spathelf P, Larsen JB, Bauhus J, Boncina A, Chauvin C, Drossler L, GarciaGuemes C, Heiri C, Kerr G, Lexer MJ, Mason B, Mohren F, Muhlethaler U, Nocentini S, Svoboda M (2014) Suitability of close-to-nature silviculture for adapting temperate European forests to climate change. Forestry 87:492503. https://doi.org/10.1093/forestry/cpu018

Březina I, Dobrovolný L (2011) Natural regeneration of sessile oak under different light conditions. J For Sci 57:359-368

Brumhard A (1843) Ueber das Lichtbedürfnis der Eiche, mit besonderer Rücksicht auf ihre Erziehung in der Vermischung mit der Buche (On the light demand of oak, with special regard to its management in mixture with beech). Allg Forst- Jagdztg 12:399-400

Burckhardt H (1870) Säen und Pflanzen nach forstlicher Praxis - Handbuch der Holzerziehung (Sowing and planting in forestry). 4th edn. Carl Rümpler, Hannover

Bußler H, Loy H (2004) Xylobionte Käferarten im Hochspessart als Weiser naturnaher Strukturen (Saproxylic beetles in the upper Spessart mountains as indicators of semi-natural forest structures). LWF-Wissen 46:36-42

Bütler R, Lachat T, Larrieu L, Paillet Y (2013) Habitat trees: key elements for forest biodiversity. In: Kraus D, Krumm F (eds) Integrative approaches as an opportunity for the conservation of forest biodiversity. European Forest Institute, Joensuu, pp 84-91

Collet C, Manso R, Barbeito I (2017) Coexistence, association and competitive ability of Quercus petraea and Quercus robur seedlings in naturally regenerated mixed stands. For Ecol Manag 390:36-46. https://doi.org/10. 1016/j.foreco.2017.01.021

Collet C, Ningre F, Frochot H (1998) Modifying the microclimate around young oaks through vegetation manipulation: effects on seedling growth and branching. For Ecol Manag 110:249-262. https://doi.org/10.1016/S0378-1127(98)00284-9

Crouzeilles R, Curran M, Ferreira MS, Lindenmayer DB, Grelle CEV, Benayas JMR (2016) A global meta-analysis on the ecological drivers of forest restoration success. Nat Commun 7:11666. https://doi.org/10.1038/ncomms11666

Diaci J, Gyoerek N, Gliha J, Nagel TA (2008) Response of Quercus robur L. seedlings to north-south asymmetry of light within gaps in floodplain forests of Slovenia. Ann for Sci 65:105. https://doi.org/10.1051/forest:2007077

Dillen M, Smit C, Verheyen K (2017) How does neighbourhood tree species composition affect growth characteristics of oak saplings? For Ecol Manag 401:177-186. https://doi.org/10.1016/j.foreco.2017.07.016

Dobrowolska D (2008) Effect of stand density on oak regeneration in flood plain forests in lower Silesia, Poland. Forestry 81:511-523. https://doi.org/10.1093/ forestry/cpn025

Dong PH, Eder W, Muth M (2007) Traubeneichen-Läuterungssversuche im Pfälzerwald (Tending experiments in young oak stands in the Palatinate forest). Mitt Forsch.Anst Waldökol Forstw RLP 63:57-77

Drobyshev I, Niklasson M, Linderson H, Sonesson K, Karlsson M, Nilsson SG, Lanner J (2008) Lifespan and mortality of old oaks - combining empirical and modelling approaches to support their management in southern Sweden. Ann For Sci 65:401-401. https://doi.org/10.1051/forest:2008012

Drößler L, Attocchi G, Monrad Jensen A (2012) Occurrence and management of oak in southern Swedish forests. Forstarchiv 83:163-169. https://doi.org/10. 4432/0300-4112-83-163

Eliasson P, Nilsson SG (2002) 'You should hate young oaks and young noblemen': the environmental history of oaks in eighteenth- and nineteenth-century Sweden. Environ Hist 7:659-674. https://doi.org/10.2307/3986064

Fahrmeir L, Kneib T, Lang S, Marx B (2013) Regression: models, methods and applications. Springer, Berlin and Heidelberg

Fleder W (1994) Zur Behandlung von jungen Traubeneichenbeständen (Management of young sessile oak stands). Forstw Cbl 112:159-169. https:// doi.org/10.1007/BF02742145

Fuchs J (1824) Vollständiges Lehrbuch die Eiche natürlich-künstlich und schnellwachsend zu erziehen (Complete textbook on how to raise oaks naturally-artificially and fast-growing). Leop. Fr. Haller, Brünn

Gauer J, Aldinger E (2005) Waldökologische Naturräume Deutschlands: Forstliche Wuchsgebiete und Wuchsbezirke (Forest ecologically based natural geographic regions of Germany: forest growth areas and growth districts). Mitt Ver forstl Standortskd Forstpflanzenzücht 43:1-324

Gayer K (1884) Die neue Wirthschaftsrichtung in den Staatswaldungen des Spessarts (The new management approach in the state forests of the Spessart mountains). Rieger, München
Gayer K (1886) Der gemischte Wald, seine Begründung und Pflege, insbesondere durch Horst- und Gruppenwirtschaft (The mixed forest). Verlag von Paul Parey, Berlin

Glaser FF, Hauke U (2004) Historisch alte Waldstandorte und Hutewälder in Deutschland (Ancient woodlands and wood pastures in Germany). Angew Landsch.ökol 61:1-193

Götmark F, Kiffer C (2014) Regeneration of oaks (Quercus robur/Q. petraea) and three other tree species during long-term succession after catastrophic disturbance (windthrow). Plant Ecol 215:1067-1080. https://doi.org/10.1007/ s11258-014-0365-4

Harmer R, Boswell R, Robertson M (2005) Survival and growth of tree seedlings in relation to changes in the ground flora during natural regeneration of an oak shelterwood. Forestry 78:21-32. https://doi.org/10.1093/forestry/cpi003

Hase W (1997) Wald- und Forstchronologie Schleswig-Holsteins seit der Nacheiszeit (Chronology of forests in Schleswig-Holstein). Struve's Buchdruckerei und Verlag, Eutin

Hauskeller-Bullerjahn K (1997) Wachstum junger Eichen unter Schirm (Growth of young oaks under the canopy). Ber Forsch.Zentr Waldökosys a 147:1-142

Hesmer H, Schroeder F-G (1963) Waldzusammensetzung und Waldbehandlung im Niedersächsischen Tiefland westlich der Weser und in der Münsterschen Bucht bis zum Ende des 18. Jahrhunderts. Forstgeschichtlicher Beitrag zur Klärung der natürlichen Holzartenzusammensetzung und ihrer künstlichen Veränderungen bis in die frühe Waldbauzeit (Forest composition and management in the western lowlands of Lower Saxony and in the Westphalian bight until the end of the 18th century). Decheniana, Beiheft 11: $1-304$

Hochbichler E, Krapfenbauer A (1988) Behandlungsprogramme für die Werteichenproduktion im Wienerwald und Weinviertel (Silvicultural guide for the production of valuable oaks in the Wienerwald and Weinviertel). Cbl ges Forstw 105:1-23

Hölzl R (2010) Historicizing sustainability: German scientific forestry in the eighteenth and nineteenth centuries. Science Culture 19:431-460. https://doi. org/10.1080/09505431.2010.519866

Humphrey JW, Swaine MD (1997) Factors affecting the natural regeneration of Quercus in Scottish oakwoods. I. Competition from Pteridium aquilinum. J Appl Ecol 34:577-584

Jacobi CG (1761) Abhandlung von der rechten Art die Eichbäume zu säen, zu pflanzen und zu erhalten (Essay on the right way of sowing, planting and preserving oak trees). Johann Jacob Curts, Halle

Jensen AM, Götmark F, Löf M (2012) Shrubs protect oak seedlings against ungulate browsing in temperate broadleaved forests of conservation interest: a field experiment. For Ecol Manag 266:187-193. https://doi.org/10.1016/j. foreco.2011.11.022

Jensen AM, Löf M (2017) Effects of interspecific competition from surrounding vegetation on mortality, growth and stem development in young oaks (Quercus robur). For Ecol Manag 392:176-183. https://doi.org/10.1016/j.foreco. 2017.03.009

Kamler J, Dobrovolný L, Drimaj J, Kadavy J, Kneifl M, Adamec Z, Knott R, Martinik A, Plhal R, Zeman J, Hrbek J (2016) The impact of seed predation and browsing on natural sessile oak regeneration under different light conditions in an over-aged coppice stand. iForest 9:569-576. https://doi.org/10.3832/ ifor1835-009

Kleinn C, Vilčko F (2006) Design-unbiased estimation for point-to-tree distance sampling. Can J For Res 36:1407-1414. https://doi.org/10.1139/x06-038

Ko YZ, Thiry W, Pelz E, Ehrlenspiel G (1969) 6-Baum-Stichprobe für die Forsteinrichtung (Six-tree sampling for forest inventories). Allg Forst- Jagdztg 140:186-189

Kohler M, Pyttel P, Schaubhut S, Hagge-Ellhöfft K, Bauhus J (2015) Über Wissen und Unwissen zur natürlichen Verjüngung der Traubeneiche - Eine Literaturstudie (Knowledge and ignorance about the natural regeneration of sessile oak - a literature study). Professur für Waldbau der Albert-LudwigsUniversität Freiburg, Freiburg (Brsg)

Krahl-Urban J (1959) Die Eichen - forstliche Monographie der Traubeneiche und der Stieleiche (The oaks, a monograph). Paul Parey, Hamburg

Kramer H, Akça A (2008) Leitfaden zur Waldmesslehre (Guidelines for dendrometry and forest inventory). 5th edn. J. D. Sauerländers Verlag, Bad Orb

Kunkel FW (1830) Betrachtungen über das Verschwinden der Eichen, hauptsächlich in den Buchenhochwaldungen (Reflections on the disappearance of the oaks, mainly in beech high forests). Allg Forst- Jagdztg 6 (A.F.):441-446 
Leibundgut H (1978) Die Waldpflege (Silviculture). 2nd edn. Haupt, Bern Leonardsson J, Löf M, Götmark F (2015) Exclosures can favour natural regeneration of oak after conservation-oriented thinning in mixed forests in Sweden: a 10-year study. For Ecol Manag 354:1-9. https://doi.org/10.1016/j. foreco.2015.07.004

Lessard V, Reed DD, Monkevich N (1994) Comparing n-tree distance sampling with point and plot sampling in northern Michigan forest types. North J Appl For 11:12-16. https://doi.org/10.1093/njaf/11.1.12

Leuschner C, Ellenberg H (2017) Ecology of central European forests (Vegetation ecology of Central Europe, volume 1). Springer, Berlin and Heidelberg

Ligot G, Balandier P, Fayolle A, Lejeune P, Claessens H (2013) Height competition between Quercus petraea and Fagus sylvatica natural regeneration in mixed and uneven-aged stands. For Ecol Manag 304:391-398. https://doi.org/10. 1016/j.foreco.2013.05.050

Löf M, Brunet J, Filyushkina A, Lindbladh M, Skovsgaard JP, Felton A (2016) Management of oak forests: striking a balance between timber production, biodiversity and cultural services. Int J Biodivers Sci Ecosyst Serv Manage 12: 59-73. https://doi.org/10.1080/21513732.2015.1120780

Löf M, Rydberg D, Bolte A (2006) Mounding site preparation for forest restoration: survival and short term growth response in Quercus robur $\mathrm{L}$. seedlings. For Ecol Manag 232:19-25. https://doi.org/10.1016/j.foreco.2006.05. 003

Magura T, Bogyó D, Mizser S, Nagy DD, Tothmeresz B (2015) Recovery of grounddwelling assemblages during reforestation with native oak depends on the mobility and feeding habits of the species. For Ecol Manag 339:117-126. https://doi.org/10.1016/j.foreco.2014.12.015

Mandallaz D (1995) "Le hasard fait bien les choses": statistical methods for forest inventory. Schweiz Z Forstwes 146:1015-1032

Milberg P, Bergman K, Sancak K, Jansson N (2016) Assemblages of saproxylic beetles on large downed trunks of oak. Ecol Evol 6:1614-1625. https://doi. org/10.1002/ece3.1935

ML, MU (2018) NATURA 2000 in niedersächsischen Wäldern - Leitfaden für die Praxis (Natura 2000 in the forests of Lower Saxony). Niedersächsisches Ministerium für Ernährung, Landwirtschaft und Verbraucherschutz; Niedersächsisches Ministerium für Umwelt, Energie, Bauen und Klimaschutz, Hannover

Moilanen A, Wilson KA, Possingham H (eds) (2009) Spatial conservation prioritization: quantitative methods and computational tools. Oxford University Press, Oxford

Mölder A, Meyer P, Nagel R-V (2019) Integrative management to sustain biodiversity and ecological continuity in central European temperate oak (Quercus robur, Q. petraea) forests: an overview. For Ecol Manag 437:324-339. https://doi.org/10.1016/j.foreco.2019.01.006

Mölder A, Nagel R-V, Meyer P, Schmidt M, Rumpf H, Spellmann H (2017) Historischer Rückblick auf die Verjüngung von Eichen im Spessart des 19. Jahrhunderts - Bedeutung der angewandten Verfahren für die heutige Eichenwirtschaft (Historical retrospective of 19th century oak regeneration in the Spessart Mountains (Germany) - the importance of former silvicultural techniques for today's oak management). Forstarchiv 88:67-78. https://doi. org/10.4432/0300-4112-88-67

Moore CT, Conroy MJ (2006) Optimal regeneration planning for old-growth forest: addressing scientific uncertainty in endangered species recovery through adaptive management. For Sci 52:155-172. https://doi.org/10.1093/ forestscience/52.2.155

Mosandl R, El Kateb H, Ecker J (1991) Untersuchungen zur Behandlung von jungen Eichenbeständen (Investigations of various thinning treatments in young oak stands). Forstw Cbl 110:358-370. https://doi.org/10.1007/ BF02741269

Noack M (2013) Neue waldkundliche Erkenntnisse zur Trauben-Eiche im nordostdeutschen Tiefland und Schlussfolgerungen für die forstliche Praxis (New silvicultural findings on sessile oak in the northeast German lowlands and conclusions for forestry). Ebersw Forstl Schriftenr 53:47-71

Nothdurft A, Saborowski J, Nuske RS, Stoyan D (2010) Density estimation based on k-tree sampling and point pattern reconstruction. Can J For Res 40:953967. https://doi.org/10.1139/X10-046

Nychka D, Furrer R, Paige J, Sain S (2016) Fields: tools for spatial data. http:// CRAN.R-project.org/package=fields

Ostrogović MZ, Sever K, Anić I (2010) Utjecaj svjetla na prirodno pomlađivanje hrasta lužnjaka (Quercus robur L.) u park-šumi Maksimir u Zagrebu (Influence of light on natural regeneration of pedunculate oak (Quercus robur L.) in the Maksimir Forest Park in Zagreb). Šumarski list 134:115-122
Otto D, Wagner S, Brang P (2009) Konkurrenz zwischen Stieleiche und Buche auf Lothar-Sturmflächen (Competition between pedunculate oak and European beech on Lothar windthrow areas). Schweiz Z Forstwes 160:114-123. https://doi.org/10.3188/szf.2009.0114

Petucco C, Skovsgaard JP, Jensen FS (2013) Recreational preferences depending on thinning practice in young even-aged stands of pedunculate oak (Quercus robur L.): comparing the opinions of forest and landscape experts and the general population of Denmark. Scand J For Res 28:668-676. https:// doi.org/10.1080/02827581.2013.825006

Picard N, Kouyate AM, Dessard H (2005) Tree density estimation using a distance method in Mali savanna. For Sci 51:7-18

Pilskog HE, Sverdrup-Thygeson A, Evju M, Framstad E, Birkemoe T (2018) Longlasting effects of logging on beetles in hollow oaks. Ecol Evol 8:10126-10137. https://doi.org/10.1002/ece3.4486

Pommerening A, Murphy ST (2004) A review of the history, definitions and methods of continuous cover forestry with special attention to afforestation and restocking. Forestry 77:27-44. https://doi.org/10.1093/forestry/77.1.27

Prodan M (1968) Punktstichprobe für die Forsteinrichtung (Point sampling for forest inventory). Forst- Holzwirt 23:225-226

Ratzeburg JTC (1860) Die Waldverderber und ihre Feinde. Fünfte vielfach verbesserte und vermehrte Auflage (Forest pests and their enemies). 5th edn. Nicolaische Verlagsbuchhandlung, Berlin

Reif A, Gärtner S (2008) Die natürliche Verjüngung der laubabwerfenden Eichenarten Stieleiche (Quercus robur L.) und Traubeneiche (Quercus petraea Liebl.) - eine Literaturstudie mit besonderer Berücksichtigung der Waldweide (Natural regeneration of the deciduous oak species pedunculate oak (Quercus robur L.) and sessile oak (Quercus petraea Liebl.) - a literature review with focus on wood pasture). Waldökol onl 5:79-116

Saha S, Kuehne C, Kohnle U, Brang P, Ehring A, Geisel J, Leder B, Muth M, Petersen R, Peter J, Ruhm W, Bauhus J (2012) Growth and quality of young oaks (Quercus robur and Quercus petraea) grown in cluster plantings in Central Europe: a weighted meta-analysis. For Ecol Manag 283:106-118. https://doi.org/10.1016/j.foreco.2012.07.021

Scheipl F (2011) SpikeSlabGAM: Bayesian variable selection, model choice and regularization for generalized additive mixed models in $\mathrm{R}$. J Stat Softw 43:1-24

Scheipl F, Fahrmeir L, Kneib T (2012) Spike-and-slab priors for function selection in structured additive regression models. J Am Stat Assoc 107:1518-1532. https://doi.org/10.1080/01621459.2012.737742

Schelhaas M-J, Nabuurs G-J, Hengeveld G, Reyer C, Hanewinkel M, Zimmermann NE, Cullmann D (2015) Alternative forest management strategies to account for climate change-induced productivity and species suitability changes in Europe. Reg Environ Chang 15:1581-1594. https://doi.org/10.1007/s10113015-0788-z

Schmidt M, Mölder A, Schönfelder E, Engel F, Schmiedel I, Culmsee H (2014) Determining ancient woodland indicator plants for practical use: a new approach developed in Northwest Germany. For Ecol Manag 330:228-239. https://doi.org/10.1016/j.foreco.2014.06.043

Schmidt W (2000) Eiche, Hainbuche oder Rotbuche? Zur Vegetation und Baumartenzusammensetzung von stau- und grundwasserbeeinflußten Wäldern des nordwestdeutschen Tieflandes. Ergebnisse aus den Naturwäldern Hasbruch und Pretzetzer Landwehr (Oak, hornbeam or beech? Vegetation and tree species composition of waterlogged and groundwater soils in the lowlands of northwestern Germany. Results from the forest nature reserves Hasbruch and Pretzetzer Landwehr). Tuexenia 20:21-44

Sheil D, Ducey MJ, Sidiyasa KD, Samsoedin I (2003) A new type of sample unit for the efficient assessment of diverse tree communities in complex forest landscapes. J Trop For Sci 15:117-135

Skiadaresis G, Saha S, Bauhus J (2016) Oak group planting produces a higher number of future crop trees, with better spatial distribution than row planting. Forests 7:289. https://doi.org/10.3390/f7110289

Skrzyszewski J, Pach M (2015) Crookedness of pedunculate oak (Quercus robur L.) growing under a canopy of scots pine (Pinus sylvestris L.). Scand J For Res 30: 688-698. https://doi.org/10.1080/02827581.2015.1048713

Solymos R (1993) Improvement and silviculture of oaks in Hungary. Ann For Sci 50:607-614. https://doi.org/10.1051/forest:19930609

Spellmann H (2001) Bewirtschaftung der Eiche auf der Grundlage waldwachstumskundlicher Untersuchungen in Nordwestdeutschland (Oak management based of forest growth studies in northwestern Germany). Beitr Forstwirtsch Landschökol 35:145-152

Spiecker H (2007) Zur Steuerung des Dickenwachstums und der Astreinigung wertvoller Trauben- und Stieleichen (Controlling diameter growth and 
natural pruning of valuable sessile and pedunculate oaks (Quercus petraea [Matt.] Liebl. and Quercus robur L.)). Mitt Forsch.Anst Waldökol Forstw RLP 63: 78-95

Stähr F (2008) Waldwirtschaft mit Hähersaat? - Zur Übernahmefähigkeit von Eichen-Naturverjüngung (Forest management by jay-sowing? About the chances of integrating natural oak regeneration). Ebersw Forstl Schriftenr 35: 8-16

Staupendahl K (2008) Die modifizierte 6-Baum-Stichprobe - ein geeignetes Verfahren zur Erfassung von Waldbeständen (The modified six-tree-sample a suitable method for forest stand assessment). Allg Forst- Jagdztg 179:21-33

Struck G (1999) Effekte von Pflanzverband, Kulturdüngung und Schlagräumung am Beispiel junger Traubeneichenbestände (Effects of planting scheme, fertilization and slash clearing in young sessile oak stands). Hainholz Forstwissenschaften 8:1-196

Thünen-Institut (2014) Third National Forest Inventory - results database. https:// bwi.info/

Valtinat K, Bruun HH, Brunet J (2008) Restoration of oak forest: effects of former arable land use on soil chemistry and herb layer vegetation. Scand J For Res 23:513-521. https://doi.org/10.1080/02827580802545572

Vodka S, Konvicka M, Cizek L (2009) Habitat preferences of oak-feeding xylophagous beetles in a temperate woodland: implications for forest history and management. J Insect Conserv 13:553-562. https://doi.org/10.1007/ s10841-008-9202-1

Lüpke B von (1998) Silvicultural methods of oak regeneration with special respect to shade tolerant mixed species. For Ecol Manag 106:19-26. https://doi.org/ 10.1016/50378-1127(97)00235-1

Lüpke B von (2007) Einfluss unterschiedlicher Hiebsformen auf die Naturverjüngung eines Traubeneichen-Buchen-Mischbestandes (Influence of various cutting types on natural regeneration of a sessile oak-beech mixed stand). Mitt Forsch.anst Waldökol Forstw RLP 63:23-56

Manteuffel HE von (1874) Die Eiche, deren Anzucht, Pflege und Abnutzung (The oak, its cultivation, management and harvest). 2nd edn. Arnoldische Buchhandlung, Leipzig

Sierstorpff CH von (1796) Ueber die forstmäßige Erziehung, Erhaltung und Benutzung der vorzüglichsten inländischen Holzarten. Erster Theil, welcher die Forst-Botanik, die Naturkunde der Bäume überhaupt, und die Beschreibung der Eiche enthält (On breeding, conserving and utilizing of the most excellent domestic tree species. First part, which includes forest botany, the general natural history of trees, and the description of oak). Gebrüder Hahn, Hannover

Wagner S, Röker B (2000) Birkenanflug in Stieleichenkulturen (Natural birch seeding in pedunculate oak plantations). Forst Holz 55:18-22

Wilbrand LW (1893) Forstästhetik in Wissenschaft und Wirthschaft (Forest aesthetics in science and management). Allg Forst- Jagdztg 69:73-80, 117-123

Winter S, Lüderitz M, Rzanny M (2015) Unterirdische Kontinuität und Pilzvielfalt alter Waldstandorte (Underground continuity and fungi diversity of old forest sites). Schweiz Z Forstwes 166:83-90. https://doi.org/10.3188/szf.2015.0083

Wood SN (2011) Fast stable restricted maximum likelihood and marginal likelihood estimation of semiparametric generalized linear models. J Royal Stat Soc Series B 73:3-36. https://doi.org/10.1111/j.1467-9868.2010.00749x

Zacharias D (1996) Flora und Vegetation von Wäldern der Querco-Fagetea im nördlichen Harzvorland Niedersachsens - unter besonderer Berücksichtigung der Eichen-Hainbuchen-Mittelwälder (Flora and vegetation of Querco-Fagetea woodlands in the northern surroundings of the Harz mountains, Lower Saxony). Nat.schutz Landsch.pfl. Niedersachs 35:1-150

\section{Submit your manuscript to a SpringerOpen ${ }^{\circ}$ journal and benefit from:}

- Convenient online submission

- Rigorous peer review

- Open access: articles freely available online

High visibility within the field

- Retaining the copyright to your article

Submit your next manuscript at $\boldsymbol{\nabla}$ springeropen.com 